CLINICAL STUDY

\title{
Increased circulating levels of FGF23: an adaptive response in primary hyperparathyroidism?
}

\author{
Janneke E Witteveen, Antoon H van Lierop, Socrates E Papapoulos and Neveen A T Hamdy \\ Department of Endocrinology and Metabolic Diseases, Leiden University Medical Center, Albinusdreef 2, 2333 ZA Leiden, The Netherlands \\ (Correspondence should be addressed to N A T Hamdy; Email: n.a.t.hamdy@lumc.nl)
}

\begin{abstract}
Introduction: Fibroblast growth factor 23 (FGF23) and parathyroid hormone (PTH) are major players in the bone-parathyroid-kidney axis controlling phosphate homeostasis. In patients with primary hyperparathyroidism (PHPT), data on the relationship between PTH and FGF23 are scarce and not always concordant.

Objective: The aim of our study was to evaluate the relationship between PTH and FGF23 in patients with PHPT and in euparathyroid patients cured after successful parathyroidectomy (PTx).

Patients and methods: Twenty-one patients with PHPT and 24 patients in long-term cure after successful PTx (EuPTH) were studied. All patients underwent biochemical evaluation of renal function, parathyroid status, vitamin D status, bone turnover markers, and serum intact FGF23 levels.

Results: Mean serum FGF23 concentration was significantly higher in PHPT than in EuPTH patients $(50.8 \pm 6.1$ vs $33.1 \pm 2.6 \mathrm{pg} / \mathrm{ml}, P=0.01)$. FGF23 levels significantly correlated with PTH levels $(r=$ $0.361, P=0.02)$, also after correction for $1,25(\mathrm{OH})_{2} \mathrm{D}$ levels $(r=0.419, P=0.01)$. FGF23 levels showed a significant negative correlation with $1,25(\mathrm{OH})_{2} \mathrm{D}$, which was more pronounced in PHPT than in EuPTH patients $(r=-0.674, P=0.001$, vs $r=-0.509, P=0.01$ ).

Conclusion: Our findings suggest that in PHPT, FGF23 levels are increased independent of $1,25(\mathrm{OH})_{2} \mathrm{D}$ levels. The more pronounced negative relationship between FGF2 3 and $1,25(\mathrm{OH})_{2} \mathrm{D}$ in the presence of high circulating PTH levels suggests that the increase in FGF23 levels may be an adaptive mechanism to counteract the PTH-induced increase in $1,25(\mathrm{OH})_{2} \mathrm{D}$ levels, although not completely overriding it.
\end{abstract}

European Journal of Endocrinology 166 55-60

\section{Introduction}

Parathyroid hormone (PTH) and the active metabolite of vitamin $\mathrm{D}\left(1,25(\mathrm{OH})_{2} \mathrm{D}\right)$ are prime regulators of calcium homeostasis but also have significant effects on phosphate homeostasis by downregulating or upregulating the sodium phosphate co-transporters in the proximal tubules of the kidneys and in enterocytes of the intestinal tract (1-8). However, the major player of the bone-kidney axis controlling phosphate homeostasis has been shown to be fibroblast growth factor 23 (FGF23). FGF23 acts as a phosphaturic factor by the same mechanism of action as PTH, downregulating the co-transporters $\mathrm{NaPi} 2 \mathrm{a}$ and $\mathrm{NaPi} 2 \mathrm{c}$ in the kidney after binding to its receptor, FGFR 1 , in the presence of Klotho (9-11). FGF23 also decreases $1,25(\mathrm{OH})_{2} \mathrm{D}$ synthesis in the proximal tubules by direct inhibition of the $1 \alpha$-hydroxylase enzyme $(9,10,12)$.

FGF23 is predominantly produced and secreted by osteocytes in bone $(9,10)$. This process is positively regulated by $1,25(\mathrm{OH})_{2} \mathrm{D}$, via a vitamin $\mathrm{D}$ response element in the $f g f 23$ promoter $(9,13-15)$. The process is also regulated by serum phosphate, although the exact mechanism by which this is achieved remains unclear. Extracellular phosphate does not appear to directly stimulate FGF 23 mRNA levels or $f g f 23$ promoter activity in osteoblastic cultures $(9,14)$. Data on the effect of changes in phosphate intake on FGF23 concentrations are inconsistent, with different responses observed with short-term or long-term alterations in phosphate intake (16-20). It has also been shown that early and rapid changes in renal phosphate excretion occur following a high-phosphorus meal, independent of FGF23, PTH, secreted frizzledrelated protein (sFRP4), or $1,25(\mathrm{OH})_{2} \mathrm{D}$, suggesting the presence of an intestinal 'phosphate sensor', although its exact biochemical nature is not known (21-25).

The PTH/PTHrP receptor (PTHR1) is present on osteocytes (26) and constitutive activation of this receptor has been shown to upregulate FGF23 mRNA expression in vitro $(27,28)$. Administration of PTH $(1-34)$ in mice and in healthy individuals is associated with an increase in $1,25(\mathrm{OH})_{2} \mathrm{D}$ and in serum FGF23 levels and with a decrease in serum phosphate levels $(13,28,29)$. In contrast, although intermittent administration of PTH to postmenopausal women 
with osteoporosis induced an increase in $1,25(\mathrm{OH})_{2} \mathrm{D}$ and in FGF23 levels, this was not associated with a decrease in serum phosphate levels (30). Taken together, these data suggest that PTH is a regulator of FGF23 synthesis and that this is likely to be independent of serum phosphate concentrations.

In patients with primary hyperparathyroidism (PHPT), data on the relationship between PTH and FGF23 are scarce and not always concordant. Compared with healthy controls, circulating FGF23 levels have been found to be elevated in patients with PHPT before parathyroidectomy (PTx) $(31,32)$ and to decrease immediately post-operatively (32), supporting the notion that PTH stimulates FGF23 secretion. However, this post-operative normalization of FGF23 levels was not observed in all studies $(31,33)$, or was observed only transiently post-PTx, with FGF23 levels returning to the originally high pre-operative values 7 days after surgery (32). The latter data suggest a possible alteration in FGF23 regulation, independent of PTH levels, in patients with PHPT. The aim of our study was to address the relationship between PTH and FGF23 in patients with PHPT and in those with this disorder after cure following successful PTx.

\section{Patients and methods}

\section{Study population}

Twenty-one consecutive patients with PHPT, which was untreated, persistent or recurrent after PTx and 24 consecutive euparathyroid patients who had a successful PTx for sporadic PHPT at the Leiden University Medical Center (LUMC) were invited and agreed to take part in the study over an 18 months period. All patients were under regular follow-up at the Outpatient Clinic of the Department of Endocrinology and Metabolic Diseases of the LUMC, with patients with persistent hyperparathyroidism being followed more closely than those cured after PTx, who were mostly seen at 1- to 2-year intervals.

The diagnosis of PHPT was established on the basis of a serum PTH concentration above the upper limit of the normal laboratory reference range $(>8 \mathrm{pmol} / \mathrm{l})$ in the presence of a high or inappropriately normal serum calcium concentration $(>2.55 \mathrm{mmol} / \mathrm{l})$. Eight of these latter patients had PTH concentrations of $13.6 \pm 2.2 \mathrm{pmol} / \mathrm{l}$ (range $8.4-27.4 \mathrm{pmol} / \mathrm{l})$ in the presence of a normal serum calcium (serum calcium $2.46 \pm 0.02$, range $2.38-2.52 \mathrm{mmol} / \mathrm{l}$ ) and in the absence of vitamin D deficiency $\left(25(\mathrm{OH}) \mathrm{D}_{3} 55.6 \pm 7.2\right.$, range $35-93 \mathrm{nmol} / \mathrm{l}$ ). Four of these eight patients had a genetically confirmed MEN1 mutation, the other four patients had evidence for a parathyroid adenoma on localization studies and became hypercalcemic under vitamin D supplementation.
A diagnosis of cure was based on sustained normal serum calcium and PTH concentrations more than 6 months after PTx.

All patients and controls had to have a creatinine clearance $>60 \mathrm{ml} / \mathrm{min}$ to be included in the study to preclude the confounding effect of renal impairment on FGF23 levels. All patients and controls had a $25(\mathrm{OH})$ vitamin $\mathrm{D}_{3}$ level of $>30 \mathrm{nmol} / \mathrm{l}$ except for five patients who had levels between 25 and $28 \mathrm{nmol} / \mathrm{l}$. These five patients were, however, hypercalcemic $(2.72 \pm 0.02$, range $2.67-2.80 \mathrm{mmol} / \mathrm{l}$ ) with increased PTH levels (serum PTH 23.5 \pm 9.0 , range $8.6-54.3 \mathrm{pmol} / \mathrm{l}$ ) and high-normal $1,25(\mathrm{OH}) \mathrm{D}_{2}$ levels (serum $1,25(\mathrm{OH}) \mathrm{D}_{2}$ $142 \pm 20$, range $87-205 \mathrm{pmol} / \mathrm{l}$ ), which was the reason to withhold the vitamin D supplementation.

\section{Methods}

Serum biochemistry Serum concentrations of calcium (reference range $2.15-2.55 \mathrm{mmol} / \mathrm{l}$ ), albumin (reference range $34-48 \mathrm{~g} / \mathrm{l}$ ), phosphate (reference range $0.90-1.50 \mathrm{mmol} / \mathrm{l}$ ), and creatinine (reference range $44-80 \mu \mathrm{mol} / \mathrm{l}$ ) were measured using semi-automated techniques. Creatinine clearance was calculated using the Modification of Diet in Renal Disease (MDRD) formula. Serum alkaline phosphatase (ALP; reference range 40-120 U/l) was measured using a fully automated P800 modulator system (Roche BV). Serum P1NP (a marker of bone formation) and $\beta$-CTX (a marker of bone resorption) were determined using the E-170 system (Roche BV). Serum concentrations of intact PTH (reference range 1.5-8 pmol/l) were measured using the Immulite 2500 (Siemens Diagnostics, Breda, Holland). Serum 25-hydroxycholecalciferol $\left(25(\mathrm{OH}) \mathrm{D}_{3}\right.$; reference range $\left.30-120 \mathrm{nmol} / \mathrm{l}\right)$ was measured using the LIAISON 25-OH Vitamin D TOTAL assay (DiaSorin S.A./N.V., Bruxelles, Belgium) and $1,25(\mathrm{OH})_{2}$ vitamin $\mathrm{D}$ was measured using LIAISON $1,25-\mathrm{OH}_{2}$ Vitamin D TOTAL assay (DiaSorin S.A./N.V.). Serum intact FGF23 (reference range 18-50 pg/ml (34)) was measured using an immunometric assay (Kainos Laboratories, Inc., Tokyo, Japan; intra-assay coefficient of variation (CV) $6 \%$ and inter-assay CV $10 \%$ ).

\section{Statistical analysis}

Statistical analysis was performed using the SPSS 16.0 software (SPSS, Inc., Chicago, IL, USA). Results are expressed as mean \pm s.E.M. unless otherwise stated. $\chi^{2}$ test and Student's $t$-test were used as appropriate for categorical variables and continuous variables. Pearson correlation coefficients were calculated to assess correlations between FGF23, PTH, 1,25(OH $)_{2} \mathrm{D}$, creatinine clearance, phosphate, and calcium. Serum PTH, FGF23, and $1,25(\mathrm{OH})_{2} \mathrm{D}$ levels are shown in Table 1 in absolute values, but were log transformed before statistical correlation and regression analysis to correct 
Table 1 Demographic and laboratory data in 21 patients with PHPT and 24 patients in sustained cure after successful parathyroidectomy.

\begin{tabular}{|c|c|c|c|c|}
\hline & PHPT $(n=21)$ & EuPTH $(n=24)$ & Ref. range & $P$ value \\
\hline Gender (men:women) & $6: 15$ & $8: 16$ & & 0.738 \\
\hline Age (years) & $57 \pm 3$ & $63 \pm 2$ & & 0.144 \\
\hline Height $(\mathrm{cm})$ & $172 \pm 2$ & $170 \pm 1$ & & 0.279 \\
\hline Weight $(\mathrm{kg})$ & $79 \pm 6$ & $74 \pm 2$ & & 0.425 \\
\hline BMI $\left(\mathrm{kg} / \mathrm{m}^{2}\right)$ & $27 \pm 2$ & $26 \pm 1$ & & 0.664 \\
\hline \multicolumn{5}{|l|}{ Serum biochemistry } \\
\hline $\operatorname{MDRD}\left(\mathrm{ml} / \mathrm{min}\right.$ per $\left.1.73 \mathrm{~m}^{2}\right)$ & $90 \pm 5$ & $84 \pm 3$ & $>60$ & 0.376 \\
\hline Corrected calcium (mmol/l) & $2.59 \pm 0.03$ & $2.27 \pm 0.02$ & $2.15-2.55$ & 0.000 \\
\hline Phosphate $(\mathrm{mmol} / \mathrm{l})$ & $0.89 \pm 0.04$ & $1.10 \pm 0.04$ & $0.9-1.5$ & 0.000 \\
\hline $\mathrm{PTH}(\mathrm{pmol} / \mathrm{l})^{\mathrm{a}}$ & $15.2 \pm 2.4$ & $3.9 \pm 0.3$ & $1.5-8.0$ & 0.000 \\
\hline PTH (median (IQR)) & $11.7(9.4-14.6)$ & $3.7(2.6-5.5)$ & $1.5-8.0$ & 0.000 \\
\hline $25(\mathrm{OH}) \mathrm{D}_{3}(\mathrm{nmol} / \mathrm{l})$ & $48 \pm 4$ & $60 \pm 4$ & $30-120$ & 0.030 \\
\hline $1,25(\mathrm{OH})_{2} \mathrm{D}(\mathrm{pmol} / \mathrm{l})^{\mathrm{a}}$ & $163 \pm 14$ & $125 \pm 7$ & $40-140$ & 0.020 \\
\hline $1,25(\mathrm{OH})_{2} \mathrm{D}($ median $(\mathrm{IQR}))$ & $150(119-203)$ & $125(95-144)$ & $40-140$ & 0.020 \\
\hline FGF23 $(\mathrm{pg} / \mathrm{ml})^{\mathrm{a}}$ & $50.8 \pm 6.1$ & $33.1 \pm 2.6$ & $18-50$ & 0.012 \\
\hline FGF23 (median (IQR)) & $44.0(36.1-59.6)$ & $29.2(24.8-40.6)$ & $18-50$ & 0.006 \\
\hline $\operatorname{ALP}(\mathrm{U} / \mathrm{l})$ & $93 \pm 5$ & $71 \pm 4$ & $40-120$ & 0.002 \\
\hline P1NP (ng/ml) & $41.4 \pm 4.4$ & $27.4 \pm 2.4$ & $16-80$ & 0.010 \\
\hline$\beta-C T X(\mathrm{ng} / \mathrm{ml})$ & $0.31 \pm 0.04$ & $0.12 \pm 0.01$ & $0.01-0.66$ & 0.000 \\
\hline
\end{tabular}

PHPT, primary hyperparathyroidism; EuPTH, euparathyroid controls; MDRD, glomerular filtration rate; IQR, interquartile range.

${ }^{\mathrm{a}}$ Log transformed before correlation analysis.

for skewness. The relationship between several biochemical variables and FGF23 was investigated by backward regression analysis. A probability level of random difference of $\mathrm{P}<0.05$ was considered significant.

The study was approved by the local ethics committee and informed consent was obtained from all patients prior to inclusion in the study.

\section{Results}

Patients with PHPT did not differ significantly in age, gender, weight, body mass index (BMI), and renal function from those in long-term cure after successful PTx (EuPTH; Table 1).

Mean serum calcium and PTH concentrations were significantly higher and mean serum phosphate and $25(\mathrm{OH})$ vitamin $\mathrm{D}_{3}$ concentrations were significantly lower in the PHPT group compared with the EuPTH group. However, serum $1,25(\mathrm{OH})_{2} \mathrm{D}$ concentrations and the bone turnover markers, ALP, P1NP, and CTX, were significantly increased in the PHPT group compared with the EuPTH group (Table 1).

Mean serum FGF23 concentration was significantly higher in patients with PHPT than in EuPTH patients $(50.8 \pm 6.1$ vs $33.1 \pm 2.6 \mathrm{pg} / \mathrm{ml}, P=0.01$; Table 1 ). There was a significant positive relationship between PTH and FGF23 levels when PHPT and EuPTH patients were analyzed together $(r=0.361, P=0.02$; Fig. 1$)$, and this relationship was sustained and more pronounced after correction for $1,25(\mathrm{OH})_{2} \mathrm{D}$ levels $(r=0.419, P=0.01)$. There was no significant relationship between PTH and FGF23 when PHPT and EuPTH patients were analyzed separately $(r=0.187, P=0.4$, vs $r=0.114, P=0.6$ respectively).
There was also no significant relationship between PTH and $1,25(\mathrm{OH})_{2} \mathrm{D}$ levels in either PHPT patients $(r=-0.269, P=0.3)$ or EuPTH patients $(r=0.016$, $P=0.9)$ or when both groups were analyzed together $(r=0.061, P=0.7)$.

In patients with PHPT, there was a significant negative correlation between FGF23 and $1,25(\mathrm{OH})_{2} \mathrm{D}$ levels $(r=-0.674, P=0.001$; Fig. 2$)$. This relationship remained significant, albeit less marked, in EuPTH patients $(r=-0.509, P=0.01$; Fig. 2$)$. The negative relationship between FGF23 and $1,25(\mathrm{OH})_{2}$ D remained significant when all patients were pooled together $(r=-0.393, P<0.01)$. Using backward stepwise

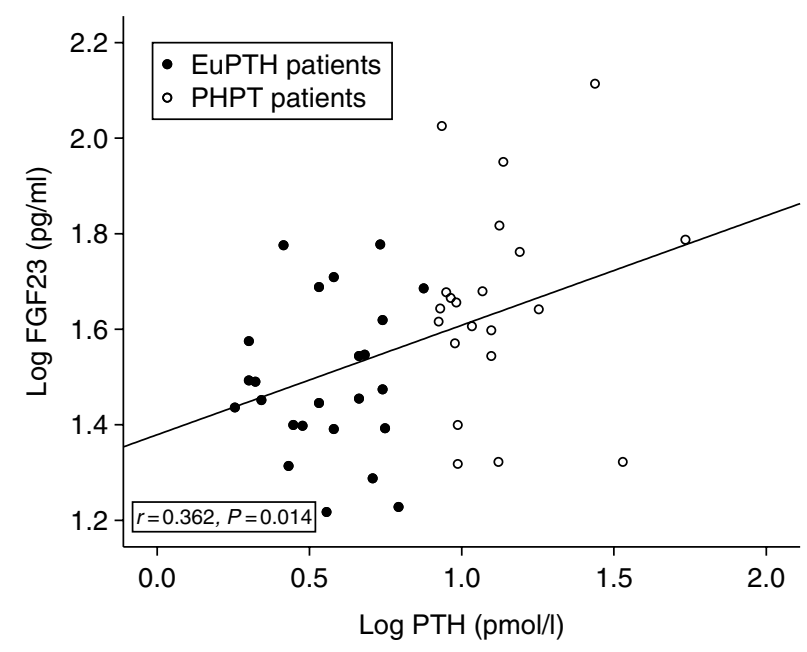

Figure 1 Relationship between serum FGF23 and PTH levels in 21 patients with primary hyperparathyroidism (PHPT: white dots) and 24 patients in long-term cure after parathyroidectomy for PHPT (EuPTH: black dots). PTH and FGF23 levels were log transformed because of skewness. 


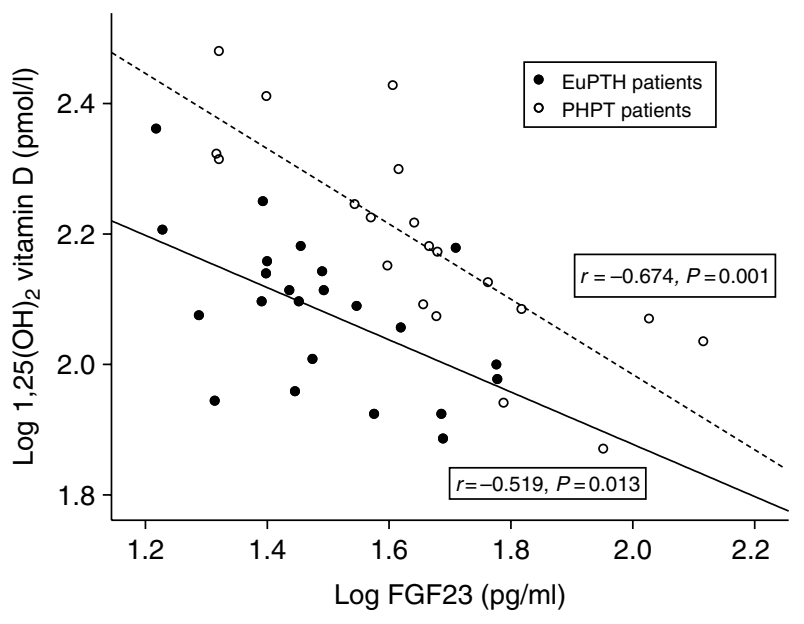

Figure 2 Relationship between serum FGF23 and $1,25(\mathrm{OH})_{2} \mathrm{D}$ levels in 21 patients with primary hyperparathyroidism (PHPT: white dots) and 24 patients in long-term cure after parathyroidectomy for PHPT (EuPTH: black dots). FGF23 and 1,25(OH $)_{2}$ D levels were log transformed because of skewness.

regression analysis, we also demonstrate that FGF23 levels exhibit significant and independent associations with PTH and $1,25(\mathrm{OH})_{2} \mathrm{D}$ levels $(\beta=0.372, P=0.015$, and $\beta=-0.429, P=0.003$ respectively; Table 2 ).

There was no significant relationship between FGF23 concentrations and creatinine clearance or serum phosphate concentrations in either PHPT patients $(r=$ $0.085, P=0.7$, and $r=0.349, P=0.09$ respectively) or EuPTH patients $(r=-0.398, P=0.06$ and $r=-0.247$, $P=0.3$ respectively). Also using backward stepwise regression analysis, creatinine clearance and serum phosphate levels failed to emerge as significant modulating factors for FGF23 levels in this model $(\beta=-0.033, P=0.811$ and $\beta=-0.068, P=0.642$ respectively; Table 2 ).

There was also no significant relationship between FGF23 levels and all three markers of bone turnover, serum ALP activity, P1NP, or CTX concentrations, in either PHPT or EuPTH patients after correction for PTH and $1,25(\mathrm{OH})_{2} \mathrm{D}$ levels.

\section{Discussion}

Data from our study show that patients with PHPT have higher levels of FGF23 than cured controls and that this increase is independent of $1,25(\mathrm{OH})_{2} \mathrm{D}$ levels.
We further demonstrate a significant negative relationship between FGF23 and $1,25(\mathrm{OH})_{2} \mathrm{D}$ levels, that is more pronounced in patients with PHPT suggesting that FGF23 at least partially antagonizes the stimulatory effects of PTH on the $1 \alpha$-hydroxylase enzyme, although not totally overriding it.

Data on FGF23 levels in PHPT and in the euparathyroid state following successful PTx are scarce and not always concordant. Two studies $(31,33)$ demonstrated no significant difference in pre- and post-PTx FGF23 levels, but a further study (32) showed a return of FGF23 levels to high pre-operative levels several days after PTx. The authors of this latter paper (32) suggested that one of the reasons for these discrepant results may be the post-operative use of active vitamin $\mathrm{D}$ metabolites or analogues in their patients, which had not been taken into consideration in the interpretation of their results. To our knowledge, FGF23 levels have never been previously evaluated in long-term euparathyroid patients after successful PTx. Our findings from this study suggest that the increase in FGF23 levels observed in PHPT is reversible when the euparathyroid state is achieved by cure after successful PTx, providing that renal function is not impaired.

Although the cross-sectional design of our study does not allow the definitive determination of a causal relationship between PTH and FGF23, our data is in keeping with recently published data in parathyroidectomized rats, in which a direct relationship between PTH and FGF23 independent of $1,25(\mathrm{OH})_{2} \mathrm{D}$ is demonstrated in the presence of high but not low levels of PTH (35).

In the presence of high PTH and FGF23 levels in patients with PHPT, it is intriguing that a significant number of these patients do not develop hypophosphatemia despite chronic exposure to the two phosphaturic hormones, PTH and FGF23. In keeping with previous observations $(13,30)$, indeed only 11 of our 22 patients with PHPT (50\%) had phosphate levels below the lower limit of normal $(<0.90 \mathrm{pmol} / \mathrm{l})$. This suggests that in PHPT, factors other than PTH, FGF23, or their combined effect may play a role in phosphate homeostasis. A clear contender is $1,25(\mathrm{OH})_{2} \mathrm{D}$. The net effect of $1,25(\mathrm{OH})_{2} \mathrm{D}$ on gut, kidney, bone, and parathyroids is to increase serum phosphate levels, by upregulating $\mathrm{NaPi} 2 \mathrm{~b}$ co-transporter expression in the intestinal tract $(1,7)$ and $\mathrm{NaPi} 2$ co-transporter $(\mathrm{NaPi} 3)$ gene in the kidney $(3,8)$ and by directly reducing PTH synthesis and secretion by the parathyroid (29).

Table 2 Result of multiple regression analysis, demonstrating a significant association between FGF23, PTH, and 1,25(OH) 2 D.

\begin{tabular}{lcrrrr}
\hline Predictor & $\boldsymbol{B}$ & S.E.M. & $\boldsymbol{\beta}$ & $\boldsymbol{t}$ & $\boldsymbol{P}$ value \\
\hline PTH & 0.895 & 0.353 & 0.372 & 2.534 & 0.015 \\
$1,25(\mathrm{OH})_{2} \mathrm{D}$ & -0.192 & 0.061 & -0.429 & -3.124 & 0.003 \\
Phosphate & -7.9595 & 16.996 & -0.068 & -0.468 & 0.642 \\
MDRD & -0.039 & 0.160 & -0.033 & -0.241 & 0.811 \\
\hline
\end{tabular}


In our study, patients with PHPT had significantly increased $1,25(\mathrm{OH})_{2} \mathrm{D}$ levels compared with euparathyroid patients, but also demonstrated significantly increased FGF23 levels. A new hypothesis has been recently proposed to explain the need for two phosphaturic hormones, PTH and FGF23, with the former repressed and the latter induced by $1,25(\mathrm{OH})_{2} \mathrm{D}(36)$. The suggested negative feedback loop includes FGF23induced inhibition of $1,25(\mathrm{OH})_{2} \mathrm{D}$ synthesis. It has been proposed that these counter-regulatory effects of FGF23 on the bone-kidney axis have the physiological task of securing the maintenance of serum phosphate levels, thus providing protection against the hyperphosphatemiarelated soft tissue and vascular calcifications (37-40). A possible explanation for the antagonizing effect of FGF23 on the $1 \alpha$-hydroxylase enzyme may be the shorter half-life of PTH compared with the longer halflife of FGF23 (41).

Our findings from this study extend our insight into the role of FGF23 in pathological states by showing that in PHPT, FGF23 production is increased in the presence of high circulating PTH levels and that this increase is reversible after the euparathyroid state is achieved following successful PTx. The more pronounced negative relationship between FGF23 and $1,25(\mathrm{OH})_{2}$ vitamin $\mathrm{D}$ in patients with PHPT suggests that in these patients the increase in FGF23 levels may be an adaptive mechanism to counteract the PTH-induced increase in $1,25(\mathrm{OH})_{2} \mathrm{D}$ levels, although not completely overriding it.

\section{Declaration of interest}

The authors declare that there is no conflict of interest that could be perceived as prejudicing the impartiality of the research reported.

\section{Funding}

This research did not receive any specific grant from any funding agency in the public, commercial, or not-for-profit sector.

\section{Acknowledgement}

We thank the Laboratories of the Departments of Endocrinology and Clinical Chemistry of the VU Medical Center, Amsterdam, The Netherlands, for performing the FGF23 measurements.

\section{References}

1 Katai K, Miyamoto K, Kishida S, Segawa H, Nii T, Tanaka H, Tani Y, Arai H, Tatsumi S, Morita K, Taketani Y \& Takeda E. Regulation of intestinal $\mathrm{Na}^{+}$-dependent phosphate co-transporters by a low-phosphate diet and 1,25-dihydroxyvitamin $\mathrm{D}_{3}$. Biochemical Journal 1999343 705-712. (doi:10.1042/02646021:3430705)

2 Kurnik BR \& Hruska KA. Mechanism of stimulation of renal phosphate transport by 1,25-dihydroxycholecalciferol. Biochimica et Biophysica Acta $1985 \mathbf{8 1 7}$ 42-50. (doi:10.1016/00052736(85)90066-5)
3 Taketani Y, Miyamoto K, Tanaka K, Katai K, Chikamori M, Tatsumi S, Segawa H, Yamamoto H, Morita K \& Takeda E. Gene structure and functional analysis of the human $\mathrm{Na}^{+} /$phosphate co-transporter. Biochemical Journal $1997 \mathbf{3 2 4} 927-934$.

4 Kurnik BR \& Hruska KA. Effects of 1,25-dihydroxycholecalciferol on phosphate transport in vitamin D-deprived rats. American Journal of Physiology 1984247 F177-F184.

5 Liang CT, Barnes J, Balakir R, Cheng L \& Sacktor B. In vitro stimulation of phosphate uptake in isolated chick renal cells by 1,25-dihydroxycholecalciferol. PNAS $1982 \quad \mathbf{7 9} \quad 3532-3536$. (doi:10.1073/pnas.79.11.3532)

6 Liang CT, Barnes J, Cheng L, Balakir R \& Sacktor B. Effects of 1,25$(\mathrm{OH})_{2} \mathrm{D}_{3}$ administered in vivo on phosphate uptake by isolated chick renal cells. American Journal of Physiology 1982242 C312-C318.

7 Virkki LV, Biber J, Murer H \& Forster IC. Phosphate transporters: a tale of two solute carrier families. American Journal of Physiology. Renal Physiology 2007293 F643-F654. (doi:10.1152/ajprenal. 00228.2007)

8 Taketani Y, Segawa H, Chikamori M, Morita K, Tanaka K, Kido S, Yamamoto H, Iemori Y, Tatsumi S, Tsugawa N, Okano T, Kobayashi T, Miyamoto K \& Takeda E. Regulation of type II renal $\mathrm{Na}^{+}$-dependent inorganic phosphate transporters by 1,25dihydroxyvitamin $\mathrm{D}_{3}$. Identification of a vitamin D-responsive element in the human NAPi-3 gene. Journal of Biological Chemistry 1998273 14575-14581. (doi:10.1074/jbc.273.23.14575)

9 Quarles LD. Endocrine functions of bone in mineral metabolism regulation. Journal of Clinical Investigation 2008118 3820-3828. (doi:10.1172/JCI36479)

10 Liu S, Gupta A \& Quarles LD. Emerging role of fibroblast growth factor 23 in a bone-kidney axis regulating systemic phosphate homeostasis and extracellular matrix mineralization. Current Opinion in Nephrology and Hypertension 200716 329-335. (doi:10.1097/MNH.0b013e3281ca6ffd)

11 Li SA, Watanabe M, Yamada H, Nagai A, Kinuta M \& Takei K. Immunohistochemical localization of Klotho protein in brain, kidney, and reproductive organs of mice. Cell Structure and Function 200429 91-99. (doi:10.1247/csf.29.91)

12 Shimada T, Hasegawa H, Yamazaki Y, Muto T, Hino R, Takeuchi Y, Fujita T, Nakahara K, Fukumoto S \& Yamashita T. FGF-23 is a potent regulator of vitamin $\mathrm{D}$ metabolism and phosphate homeostasis. Journal of Bone and Mineral Research 200419 429435. (doi:10.1359/JBMR.0301264)

13 Burnett-Bowie SM, Henao MP, Dere ME, Lee H \& Leder BZ. Effects of hPTH (1-34) infusion on circulating serum phosphate, 1,25dihydroxyvitamin D, and FGF23 levels in healthy men. Journal of Bone and Mineral Research 200924 1681-1685. (doi:10.1359/ jbmr.090406)

14 Liu S, Tang W, Zhou J, Stubbs JR, Luo Q, Pi M \& Quarles LD. Fibroblast growth factor 23 is a counter-regulatory phosphaturic hormone for vitamin D. Journal of the American Society of Nephrology $2006 \quad 17 \quad 1305-1315 . \quad$ (doi:10.1681/ASN. 2005111185)

15 Kolek OI, Hines ER, Jones MD, LeSueur LK, Lipko MA, Kiela PR, Collins JF, Haussler MR \& Ghishan FK. 1 $\alpha, 25$-Dihydroxyvitamin $\mathrm{D}_{3}$ upregulates FGF23 gene expression in bone: the final link in a renal-gastrointestinal-skeletal axis that controls phosphate transport. American Journal of Physiology. Gastrointestinal and Liver Physiology 2005289 G1036-G1042. (doi:10.1152/ajpgi. 00243.2005)

16 Burnett SM, Gunawardene SC, Bringhurst FR, Juppner H, Lee H \& Finkelstein JS. Regulation of C-terminal and intact FGF-23 by dietary phosphate in men and women. Journal of Bone and Mineral Research 2006 21 1187-1196. (doi:10.1359/jbmr.060507)

17 Ferrari SL, Bonjour JP \& Rizzoli R. Fibroblast growth factor-23 relationship to dietary phosphate and renal phosphate handling in healthy young men. Journal of Clinical Endocrinology and Metabolism 2005 90 1519-1524. (doi:10.1210/jc.2004-1039)

18 Larsson T, Nisbeth U, Ljunggren O, Juppner H \& Jonsson KB. Circulating concentration of FGF-23 increases as renal function declines in patients with chronic kidney disease, but does not 
change in response to variation in phosphate intake in healthy volunteers. Kidney International 200364 2272-2279. (doi:10. 1046/j.1523-1755.2003.00328.x)

19 Ito N, Fukumoto S, Takeuchi Y, Takeda S, Suzuki H, Yamashita T \& Fujita T. Effect of acute changes of serum phosphate on fibroblast growth factor (FGF)23 levels in humans. Journal of Bone and Mineral Research 200725 419-422. (doi:10.1007/s00774-0070779-3)

20 Nishida Y, Taketani Y, Yamanaka-Okumura H, Imamura F, Taniguchi A, Sato T, Shuto E, Nashiki K, Arai H, Yamamoto H \& Takeda E. Acute effect of oral phosphate loading on serum fibroblast growth factor 23 levels in healthy men. Kidney International 200670 2141-2147.

21 Berndt T \& Kumar R. Novel mechanisms in the regulation of phosphorus homeostasis. Physiology 200924 17-25. (doi:10. 1152/physiol.00034.2008)

22 Khoshniat S, Bourgine A, Julien M, Weiss P, Guicheux J \& Beck L. The emergence of phosphate as a specific signaling molecule in bone and other cell types in mammals. Cellular and Molecular Life Sciences 201068 205-218. (doi:10.1007/s00018-010-0527-z)

23 Berndt T, Thomas LF, Craig TA, Sommer S, Li X, Bergstralh EJ \& Kumar R. Evidence for a signaling axis by which intestinal phosphate rapidly modulates renal phosphate reabsorption. PNAS 2007104 11085-11090. (doi:10.1073/pnas.0704446104)

24 Markovich D, Verri T, Sorribas V, Forgo J, Biber J \& Murer H. Regulation of opossum kidney $(\mathrm{OK})$ cell $\mathrm{Na} / \mathrm{Pi}$ cotransport by $\mathrm{Pi}$ deprivation involves mRNA stability. Pflügers Archiv $1995 \mathbf{4 3 0}$ 459-463. (doi:10.1007/BF00373881)

25 Segawa H, Kaneko I, Yamanaka S, Ito M, Kuwahata M, Inoue Y, Kato S \& Miyamoto K. Intestinal Na-P(i) cotransporter adaptation to dietary $\mathrm{P}(\mathrm{i})$ content in vitamin $\mathrm{D}$ receptor null mice. American Journal of Physiology. Renal Physiology 2004287 F39-F47. (doi:10.1152/ajprenal.00375.2003)

26 Galitzer H, Ben-Dov I, Lavi-Moshayoff V, Naveh-Many T \& Silver J. Fibroblast growth factor 23 acts on the parathyroid to decrease parathyroid hormone secretion. Current Opinion in Nephrology and Hypertension $2008 \quad 17 \quad 363-367 . \quad$ (doi:10.1097/MNH. Ob013e328303e172)

27 Rhee Y, Farrow E, Lee R, Bivi N, Lazcano V, Plotkin L, White K \& Bellido T. FGF23 expression is upregulated by PTH receptor activation in osteocytes in vitro and in vivo: a parathyroid-bone link influencing the endocrine function of osteocytes. Journal of Bone and Mineral Research 2009 24. S1 A1039. (doi:10.1002/jbmr. 5650241301)

28 Lavi-Moshayoff V, Wasserman G, Meir T, Silver J \& Naveh-Many T. PTH increases FGF23 gene expression and mediates the highFGF23 levels of experimental kidney failure: a bone parathyroid feedback loop. American Journal of Physiology. Renal Physiology 2010299 F882-F889. (doi:10.1152/ajprenal.00360.2010)

29 Bergwitz C \& Juppner H. Regulation of phosphate homeostasis by PTH, vitamin D, and FGF23. Annual Review of Medicine $2010 \mathbf{6 1}$ 91-104. (doi:10.1146/annurev.med.051308.111339)

30 Sridharan M, Cheung J, Moore AE, Frost ML, Fraser WD, Fogelman I \& Hampson G. Circulating fibroblast growth factor23 increases following intermittent parathyroid hormone (1-34) in postmenopausal osteoporosis: association with biomarker of bone formation. Calcified Tissue International 201087 398-405. (doi:10.1007/s00223-010-9414-8)
31 Yamashita H, Yamashita T, Miyamoto M, Shigematsu T, Kazama JJ, Shimada T, Yamazaki Y, Fukumoto S, Fukagaw M \& Noguchi S. Fibroblast growth factor (FGF)-23 in patients with primary hyperparathyroidism. European Journal of Endocrinology 2004151 55-60. (doi:10.1530/eje.0.1510055)

32 Kobayashi K, Imanishi Y, Miyauchi A, Onoda N, Kawata T, Tahara H, Goto H, Miki T, Ishimura E, Sugimoto T, Ishikawa T, Inaba M \& Nishizawa Y. Regulation of plasma fibroblast growth factor 23 by calcium in primary hyperparathyroidism. European Journal of Endocrinology 2006154 93-99. (doi:10.1530/eje.1. 02053)

33 Tebben PJ, Singh RJ, Clarke BL \& Kumar R. Fibroblast growth factor 23, parathyroid hormone, and 1alpha,25-dihydroxyvitamin D in surgically treated primary hyperparathyroidism. Mayo Clinic Proceedings $2004 \mathbf{7 9}$ 1508-1513. (doi:10.4065/79.12. 1508)

34 Heijboer AC, Levitus M, Vervloet MG, Lips P, ter Wee PM, Dijstelbloem HM \& Blankenstein MA. Determination of fibroblast growth factor 23. Annals of Clinical Biochemistry $2009 \mathbf{4 6}$ 338-340. (doi:10.1258/acb.2009.009066)

35 Lopez I, Rodriguez-Ortiz E, Almaden Y, Guerrero F, Montes de Oca A, Pineda C, Shalhoub V, Rodriguez M \& AguileraTejero E. Direct and indirect effects of parathyroid hormone on circulating levels of fibroblast growth factor 23 in vivo. Kidney International 201180 475-482. (doi:10.1038/ki.2011.107)

36 Jurutka PW, Bartik L, Whitfield GK, Mathern DR, Barthel TK, Gurevich M, Hsieh JC, Kaczmarska M, Haussler CA \& Haussler MR. Vitamin D receptor: key roles in bone mineral pathophysiology, molecular mechanism of action, and novel nutritional ligands. Journal of Bone and Mineral Research 2007 22 (Suppl 2) V2-V10. (doi:10.1359/jbmr.07s216)

37 Hruska KA, Mathew S, Lund R, Qiu P \& Pratt R. Hyperphosphatemia of chronic kidney disease. Kidney International $2008 \mathbf{7 4}$ 148-157. (doi:10.1038/ki.2008.130)

38 Stubbs JR, Liu S, Tang W, Zhou J, Wang Y, Yao X \& Quarles LD. Role of hyperphosphatemia and 1,25-dihydroxyvitamin D in vascular calcification and mortality in fibroblastic growth factor 23 null mice. Journal of the American Society of Nephrology 200718 2116-2124. (doi:10.1681/ASN.2006121385)

39 Block GA, Hulbert-Shearon TE, Levin NW \& Port FK. Association of serum phosphorus and calcium $\times$ phosphate product with mortality risk in chronic hemodialysis patients: a national study. American Journal of Kidney Diseases 199831 607-617. (doi:10. 1053/ajkd.1998.v31.pm9531176)

40 Tonelli M, Sacks F, Pfeffer M, Gao Z \& Curhan G. Relation between serum phosphate level and cardiovascular event rate in people with coronary disease. Circulation 2005112 2627-2633. (doi:10. 1161/CIRCULATIONAHA.105.553198)

41 Khosravi A, Cutler CM, Kelly MH, Chang R, Royal RE, Sherry RM, Wodajo FM, Fedarko NS \& Collins MT. Determination of the elimination half-life of fibroblast growth factor-23. Journal of Clinical Endocrinology and Metabolism 200792 2374-2377. (doi:10.1210/jc.2006-2865)

Received 11 June 2011

Revised version received 16 September 2011

Accepted 7 October 2011 